\title{
Thanks for Nothing: Income and Labor Force Participation for Never-Married
}

Mothers since $1982^{*}$

\author{
Matthew McKeever
}

Mount Holyoke College

Nicholas H. Wolfinger

University of Utah

Published in Social Science Research $(2011 ; 40: 63-76)$

\footnotetext{
${ }^{*}$ Correspondence to Wolfinger, Department of Family and Consumer Studies, 225 South 1400 East, AEB 228, University of Utah, Salt Lake City, UT 84112-0080; e-mail: Nick.Wolfinger@fcs.utah.edu. We thank Sonja Anderson and Alta Williams for research assistance, Tim Bröwn, Lori Kowaleski-Jones, Rebecca Maynard, and Zac Zimmer for helpful suggestions on previous drafts, and the W. T. Grant Foundation (\#202080524) for generous funding. We also acknowledge Phil Cohen, Eanswythe Leicester Grabowski, and Linda Keiter for their kind assistance with the Current Population Survey. The two authors contributed equally to this paper, earlier drafts of which were presented at the 2006 annual meeting of the American Sociological Association in Montreal and the 2007 International Sociological Association Research Committee 28 meeting in Brno.
} 
Thanks for Nothing: Income and Labor Force Participation for Never-Married Mothers since 1982

\begin{abstract}
We examine the changing social and economic characteristics of women who give birth out of wedlock. Using Current Population Survey data collected between 1982 and 2002, we find that never-married mothers remain impoverished. Their income growth over these years was modest despite substantial gains in education, employment, and other individual characteristics generally associated with prosperity. These results affirm the ongoing role of family structure in shaping American inequality.
\end{abstract}

Key words: never-married mothers, unwed mothers, single mothers, poverty, nonmarital births 
In recent years far fewer children are being raised by two married parents (Ellsworth and Jencks 2004; Fields 2003), a trend with noteworthy implications for inequality (McLanahan 2004). Social scientists consistently document a strong correlation between family structure and income, with women who give birth out of wedlock having especially high poverty rates (M. Martin 2006; Wu and Stojnic 2007). These mothers compose a large and growing population, reflecting under 20\% of births in 1980 (Wu, Bumpass, and Musick 2001) but 39\% in 2006 (J. Martin et al. 2009). At the same time there have been many changes to America's economic structure. Both the labor market and the position of women within it have undergone radical shifts, thereby affecting the incomes of all families.

This paper examines how the incomes of women who give birth out of wedlock have changed since 1982. We explore the economics of never-married motherhood to better understand the theoretical link between family structure and inequality. Much public policy treats this link as constant: poverty, especially child poverty, is assumed to be a direct consequence of father absence. This understanding motivated both the 1996 Personal Responsibility and Work Opportunity Reconciliation Act and the more recent Healthy Marriage Initiative (U.S. Department of Health \& Human Services 2006). One principle underlying the Initiative is that poverty rates could be dramatically reduced if only higher marriage rates were attained (and divorce rates lowered). This notion was echoed by the conclusion of a 2004 Heritage Foundation report: "The collapse of marriage is the principal cause of child poverty in the United States." (Heritage Foundation 2004). Such statements reflect social science research that shows inverse relationships between marriage and poverty (Waite and Gallagher 2000). Yet most scholars would find the idea of an inherent link between family structure and poverty 
problematic, likely instead arguing that such links are both variable and worthy of scholarly scrutiny.

Using data from the 1982-2002 Current Population Survey, we find that never-married mothers have achieved impressive gains in education and employment but have not seen commensurately higher incomes. Modest economic growth has occurred at the top of the income distribution, but other never-married mothers have made little progress. These results suggest that women who give birth out of wedlock suffer from pervasive and enduring disadvantages that cannot be explained by their basic social and demographic attributes.

\section{Family Structure and Changing Family Inequality}

Family structure is now firmly entrenched with education, race, gender, age, and socioeconomic origins as a touchstone of stratification scholarship. There is little research on inequality in contemporary America that does not mention the high rate of poverty among singleheaded households. But this link between family structure and economic inequality should not be taken as constant: poverty, although common in single-mother families, is not a direct consequence of the absence of two married and working adults. Families do not necessarily have less money if they are headed by one person instead of a married couple. Prosperity is instead determined by the variable participation of family members in institutions that reward individuals with income (Lichter and Eggebeen 1994).

The goal of this paper is to explore how never-married mothers' participation in incomegranting institutions has changed from 1982 to 2002, and whether this change can explain mothers' economic fortunes over these years. There are two theoretical perspectives informing 
our research. The first, characterizing most labor market scholarship, is that people with more human capital will make more money (Coleman 1988). Generally speaking single-parent families are at a loss compared to two-parent families, simply because they have one fewer adult to either earn income in the labor market or to assist the primary wage earner. However, not all single-parent families are identical, and we expect the incomes of these families should vary according to the characteristics of the adults who head them. These characteristics include the quality of the job they hold, if any, as well as their education and experience. Furthermore, the changing distribution of these characteristics should be related to income trends for single mothers: if over time mothers are increasingly likely to be educated and employed, their incomes should have risen.

The regular labor market is not the only way people make money, as government programs, extended families, unmarried live-in partners, and the informal economy may also provide income. Although generally less lucrative than jobs, these income sources may provide needed flexibility for single mothers (Edin and Lein 1997). The amount of income received as transfers from the government and elsewhere will depend, like the formal labor market, upon family characteristics, including family size, living situation, and perhaps personal characteristics such as education and age. Thus the income received by any family is related to the number of adults with jobs, and the qualities of these individuals which may raise or lower their revenue from the labor market and elsewhere.

To understand the economics of single-mother families it is therefore important to examine the characteristics of the women who head these families. We hypothesize that nevermarried mothers are poor not because they gave birth out of wedlock but because they are unable to make money due to their qualifications, abilities, and resources. These disadvantages come on 
top of the vocational challenges traditionally associated with motherhood, most notably discrimination, reduced labor market participation, and child care responsibilities (Correll, Benard, and Paik 2007; England 1992; Treiman and Hartmann 1981; Waldfogel 1997).

This theoretical perspective on income, predicated on the ability of single mothers to obtain income from various institutions, leads us to expect economic progress for mothers who give birth out of wedlock simply because the social and economic status of American women as a whole has improved so much over the past 30 years (Collins 2009). One important change concerns education. Between 1980 and 2002 the percentage of all women with college degrees rose from $13 \%$ to $25 \%$, while high school diplomas increased from $66 \%$ to $84 \%$ (U.S. Bureau of the Census 2003). ${ }^{1}$ Employment rates for women, with or without children, have increased greatly (U.S. Bureau of the Census 2003), a long-term trend that existed even before the introduction of time limits on welfare receipt in 1996. The gender gap in wages has narrowed (U.S. Bureau of the Census 1999). Average family size has declined, lessening mothers' economic burden (U.S. Bureau of the Census 2003). Finally, nonmarital cohabitation rates have skyrocketed (Bumpass and Lu 2000), with about half of all women thought to be single mothers having lived with partners at some point during their children's lives (Bumpass and Raley 1995; McLanahan 2005). Cohabitation should give never-married mothers greater ability to make money by providing assistance with household labor (Davis, Greenstein, and Marks 2007). Alternately, a cohabiting partner could make an independent income unnecessary.

A second theoretical position concerns the possibility that income-generating institutions such as government programs and the labor market have increasingly failed to reward never-

\footnotetext{
${ }^{1}$ More recent figures are available. We report these numbers because they are more comparable to the Current Population Survey data we analyze.
} 
married mothers. The cash value of welfare payments, as measured in real dollars, has declined substantially over time (Congressional Committee on Ways and Means 2004). There have also been dramatic changes in the structure of the American workplace over the past 40 years. Ongoing bifurcation of the labor market has increasingly trapped many workers in bad jobs (Morris and Western 1999; U.S. Bureau of the Census 2010). Higher education has become more important to American workers, as the earnings gap between the high school-educated and the college-educated grows ever wider (Fischer and Hout 2006).

Perhaps these labor market changes have redounded to the disadvantage of women who give birth out of wedlock. Even though never-married mothers might be better qualified than in the past, they may not fully benefit from their qualifications simply because they are nevermarried mothers (Blank 1998; Edin and Lein 1997; McLanahan 2004). This may have been the case in the past: poverty rates for single mothers did not change appreciably between 1970 and 1984, years when their employment rates increased (Nichols-Casebolt 1988). Many single mothers work in low-wage occupations, notably in the service sector (Peterson, Song, and JonesDeWeever 2002). Childcare responsibilities and diminished opportunities to earn money in the informal economy may reduce incomes for single mothers who take jobs (Edin and Lein 1997). Entanglements with extended family members may also hold mothers back in the labor market (Stack 1974). These findings suggest that, contrary to the speculations outlined above, nevermarried mothers may not have been able to realize the economic benefits presumably conferred by education and employment. 


\section{Teen Mothers, Single Mothers, Welfare Reform, and Other Approximations}

The voluminous literature on single mothers suggests they are doing better financially. Poverty rates for mother-headed families in general reached a 40 -year low of $25 \%$ in 2000 (Dalaker 2001) before rebounding to $28 \%$ three years later (DeNavas-Walt, Proctor, and Mills 2004). It is not known if these figures represent progress for never-married mothers in particular, as little research to date has looked at the incomes of never-married mothers as a distinct population. Two recent studies have considered other dimensions of economic wellbeing for never-married mothers. Wu and Stojnic (2007) examine changing poverty rates for women who give birth out of wedlock, while Martin (2006) considers income inequality by family structure. Neither study includes multivariate analysis. Most research on the subject instead analyzes populations that include only a fraction of women who give birth out of wedlock, or fails to differentiate divorced and never-married mothers.

According to a 2003 Census report, 44\% of single mothers have never been married, while $35 \%$ are divorced (the other $21 \%$ includes widowed mothers and women separated from their spouses) (Fields 2003). Divorced women's economic woes are rooted in their marital transitions (Smock, Manning, and Gupta 1999) and in any event have abated substantially since 1980 (McKeever and Wolfinger 2001, 2005). Although (re)marriage is a traditional means of escaping poverty for single mothers, an out-of-wedlock birth reduces marriage rates (Lichter and Graefe 2001; Lichter, Graefe, and Brown 2003; Upchurch, Lillard, and Panis 2001). For these reasons never-married mothers should be studied separately.

The extensive scholarship on the consequences of welfare reform (see Blank 2002; Grogger and Karoly 2005 for reviews) seldom differentiates never-married and divorced 
mothers. Other research has focused on teenage childbearing. This work shows that some, if not all, of the apparent economic consequences of teenage childbirth are a product of selection: teenage mothers would be impoverished even had they remained childless (Geronimus and Korenman 1991; Grogger and Bronars 1993; Hoffman, Foster, and Furstenberg 1993; Hotz, McElroy, and Sanders 2005; see Hoffman 1998 for a review). There are three problems with applying studies of teenage childbearing to never-married mothers. First, one out of four teenage mothers is married (Foster, Jones, and Hoffman 1998). Second, older women who give birth out of wedlock are neglected entirely; by 1995 , only about $30 \%$ of never-married mothers were teenagers (Wu, Bumpass, and Musick 2001). Third, none of the studies cited here consider how mothers' incomes have changed over time. This is a significant omission in an era when all women's labor force prospects have improved, potentially eroding the link between nevermarried motherhood and poverty.

\section{GOALS OF ANALYSIS}

We explore how the incomes of never-married mothers changed between 1982 and 2002 . A regression of log-income explores the changing determinants of income. Decomposition analyses allow us to determine whether income variation can be attributable to changing human capital or changing returns to human capital. Our decompositions consider changes across the income distribution as well as changes in mean log-income. We also examine sample selection issues and determine whether economic dependence has affected income trends for nevermarried mothers. 
Our study begins in 1982 for two reasons. First, it marks the implementation of a new sampling strategy for the CPS; earlier data may not be directly comparable. Second, it is the first year of data to be affected by the Reagan presidency, often thought to herald a new economic regime (Kymlicka and Matthews 1988; Lekachman 1982). We end the study at 2002 because information on occupational status, described below, is not available for subsequent years.

\section{METHODS}

\section{Data and Dependent Variable}

We study never-married mothers using data from the 1982-2002 March Demographic Supplements of the Census Bureau's Current Population Survey (CPS) (U.S. Bureau of the Census 2002a). Reflecting an annually repeated cross section of over 50,000 households, the CPS data are nationally representative and contain detailed information on income and other participant characteristics. Our overall sample for these years is 34,321 . We also examine data for the years 1982 and 2002 separately; these samples are 997 and 3,133 respectively. These bookends to our time series are used primarily for decomposition analyses.

We analyze female CPS participants who have never been married and have one or more co-resident biological children under the age of 18. Participants may be householders or the children or stepchildren of householders; women in these three categories comprise $96 \%$ of all 
never-married mothers in the CPS. ${ }^{2}$ Thus we examine the extant never-married mother population, a selective sample. Our intention is to analyze the population of mothers who do not marry after childbirth and therefore are the most economically vulnerable (Lichter, Graefe, and Brown 2003). Sample selection is discussed in greater detail below.

Our main dependent variable is family income, defined as the sum of wages, selfemployment income, state transfers including social security or welfare payments, and any income from interest, rent, or child support, for all family members (based on the CPS definition of family; this excludes income produced by cohabiting partners). We study income rather than wages because income determines overall living standards. ${ }^{3}$ Mothers reporting zero or negative income are assigned incomes of ten dollars to calculate their log-incomes. Income is measured in 2002 dollars ${ }^{4}$ and survey weights are used in all analyses so the data comprise a nationally representative sample. Regression analyses employ Huber-White standard errors to avoid the artificially inflated t-ratios that can result from weighted data.

\footnotetext{
${ }^{2}$ Given how the CPS classifies household relationships it is often impossible to determine children's ages, a key independent variable, for the other $4 \%$ of never-married mothers. One example is that of never-married mothers who are part of a subfamily unrelated to the householder.
}

${ }^{3}$ We conducted preliminary analysis of wage income. In most respects, this yielded findings similar to the multivariate results reported here. The main differences were that survey year had a positive regression coefficient, children had a consistently negative relationship with earnings, and the positive net correlation between income and an early teenage birth disappeared (see Table 2).

${ }^{4}$ Income is adjusted using the Consumer Price Index (the average for the year for urban households) provided by the Bureau of Labor Statistics. We left top-coded incomes as reported in the CPS. The number of never-married mothers in this category is too small to affect our results. 


\section{Sample Selection Issues}

Sample selection bias may have affected our results in two ways. First, the population of women who give birth out of wedlock is obviously a select group. Some of the economic consequences of teenage childbirth are endogenous (Hotz, McElroy, and Sanders 2005), with many never-married mothers themselves the product of poor, unstable families (Wu 1996). Second, the population of never-married mothers who subsequently wed is not random. For instance, non-Black mothers have higher marriage rates after a non-marital birth, as do mothers whose partners have higher incomes and more education (Wilcox and Wolfinger 2007). Selection bias is possible in our analysis if the determinants of either premarital fertility or marriage for never-married mothers have changed over time.

Selection is explored using data from the 1990 and 1995 June Marriage and Fertility Supplements to the Current Population Survey (earlier surveys are not directly comparable and later surveys lack necessary information). The June CPS provides retrospective data on fertility and marriage timing, enabling us to compare trends in nonmarital fertility and marriage among never-married mothers by constructing synthetic cohorts. A disadvantage of the June CPS is that its retrospective design precludes most of the independent variables used in our main analyses.

We first conduct an event history analysis of the changing determinants of nonmarital fertility. Three independent variables are employed: CPS year, birth cohort, and race. The results of this analysis are largely consistent with the findings presented below and therefore offer little insight into sample selection issues: more women are giving birth out of wedlock, a decreasing share of whom are African-American. Given the expanding pool of women giving 
birth out of wedlock, it is unlikely that changing selection into never-married motherhood has driven our finding of waning returns to labor market characteristics.

We also explore the changing determinants of marriage among women who give birth out of wedlock, a noteworthy concern given disproportionately low marriage rates for never-married mothers. Over time marriage rates fell especially quickly for African-American never-married mothers. In addition, while older never-married mothers are less likely to marry, the inverse relationship between maternal age and the likelihood of marriage has weakened over time. Thus non-Black never-married mothers, who have higher incomes than their African-American counterparts (see Table 2), and older never-married mothers, who presumably have more job experience, have increasingly been selected into marriage. Based on these results, we conclude that changing selection into marriage has weakened never-married mother's earning potential. This is consistent with the primary finding of our paper: although never-married mothers' labor force credentials — education, employment rates, job quality—have increased, returns to these attributes have declined over time. Our results also support the literature that has suggested endogeneity in the relationship between nonmarital fertility and income (Geronimus and Korenman 1991; Grogger and Bronars 1993; Hoffman, Foster, and Furstenberg 1993; Hotz, McElroy, and Sanders 2005) by showing that the economic consequences of the endogeneity have grown stronger, partially due to increased selection into marriage.

\section{Independent Variables}

Education, occupational status, age, and hours worked allow us to examine the relationship between income and labor force characteristics. Education is dummy-coded as less than a high school degree, high school graduate, some college, college graduate, and graduate 
degree. Occupational status is measured with a SocioEconomic Index (SEI) of occupations (Hauser and Warren 1997), coded as a piecewise linear spline with a knot at $40 .^{5}$ This coding is based on exploratory analysis using generalized additive models (Hastie and Tibshirani 1990), which revealed the nonlinear relationship between SEI and log-income. Hours worked is dummy-coded as not working (0 hours), working part-time (1-34 hours), and working full-time (35+ hours). Age is a continuous variable; its square is included to account for age's curvilinear relationship to income (Thurow 1969). Together age and its square proxy work experience, information otherwise unavailable.

Second, we explore the association between fertility and never-married mothers' incomes. We use dummy variables to measure the number of children (one, two, or three or more) and the presence of children under six years old. A second set of dummies measures whether women's first nonmarital birth occurred under the age of eighteen or between eighteen and nineteen; twenty and over is the reference category. An additional dummy variable is coded for the $4 \%$ of cases missing data, the product of complexities in reconstructing household records. More sophisticated means of handling missing data, such as multiple imputation, do not perform appreciably better (Paul et al. 2008). No other variable has missing data.

A third set of independent variables allows us to determine whether never-married mothers' incomes are related to dependence on parents or cohabiting partners. These forms of co-residence have potential implications for both employment and income, and are measured

\footnotetext{
${ }^{5}$ An SEI of 40 corresponds to occupations such as sales workers in electronics, ticket agents, clerical supervisors, and mail carriers. SEI is set at zero for women who are not working, approximately $37 \%$ of the sample. These respondents are captured by the dummy variables measuring whether respondents were working full-time, part-time, or not at all. We repeated the analysis with the zero values set to the sample mean and did not obtain substantively different results.
} 
with dummy variables. The CPS only added direct means of identifying cohabiting couples in 1995, so we use the adjusted Persons of Opposite Sex Sharing Living Quarters (POSSLQ) measure proposed by Casper and Cohen (2000). ${ }^{6}$ We are not able to conduct separate analyses of cohabiting couples because of the design of the CPS. Our analyses are based on family income, but cohabiting partners are treated as unrelated individuals within a household; thus, cohabiting couples span two families according to CPS definitions. ${ }^{7}$

Race, correlated with both income (Proctor and Dalaker 2003) and non-marital fertility (Ventura 2000), is dummy-coded as White, Black, and other. Sample size considerations for the beginning of our time series preclude more detailed measures of race/ethnicity. Finally, survey year is a continuous independent variable measured as the actual four-digit calendar year.

\footnotetext{
${ }^{6}$ An adjusted POSSLQ household meets the following criteria: It must contain a householder, one other adult (age $15+$ ) of the opposite sex who is not in a related subfamily, not living in group quarters, and not related to or a foster child of the reference person, and must not contain other adults except adult relatives. This measure does not differentiate opposite-sex roommates from cohabiting partners. Nor does it permit us to identify same-sex couples. Although adjusted POSSLQ overestimates the actual number of cohabiting couples, it produces samples of cohabiting adults with social and demographic characteristics that closely resemble those generated by direct measures (Casper and Cohen 2000). These direct measures themselves are not always accurate due to the informal nature of some cohabiting relationships (Manning and Smock 2005).

${ }^{7}$ One alternative is to omit cohabiting individuals. We include them on the grounds that cohabitation, given its fundamental instability (Bumpass and Lu 2000; Wolfinger 2005), often provides only transitory economic benefit to single mothers. A second alternate is to include the incomes of cohabitating individuals as part of family income. This is problematic because married and cohabiting couples treat income much differently (Heimdal and Houseknecht 2003).
} 


\section{Analyses}

We first examine how the characteristics of never-married mothers changed over time, then perform a least squares regression of logged family income using all years of CPS data between 1982 and 2002, inclusive. The correlates of income are interacted with survey year to understand how their effects changed. Next we regress income for the end years of the study, 1982 and 2002, to decompose changes in mean log-income between 1982 and 2002 into three components: 1) the portion related to changes in personal attributes; 2) the portion due to changes in the return to these attributes; and 3) the portion due to the interaction of these two sets of factors (Duncan 1968; Jones and Kelley 1984); economists often refer to this procedure as the Oaxaca (1973) decomposition. ${ }^{8}$ Decomposition analysis allows us to pose counterfactual questions: how would income be affected if human capital changed over time but returns to human capital remained constant? How would income have changed if levels of human capital remained constant but returns to human capital changed?

We also employ a rank-order decomposition that provides insight into how changes in labor force qualifications and returns to these assets have affected women's locations within the income distribution (Fortin and Lemieux 1998). Family income is divided into 50 intervals, each containing $2 \%$ of the income distribution. This provides sufficient categories to approximate the income distribution without spreading the sample too thin. The distribution of income categories serves as a dependent variable predicted by ordered logistic regression models, which in turn facilitate a novel distributional decomposition. By decomposing entire income distributions via

\footnotetext{
${ }^{8}$ Due to sample size limitations we merge two categories, college graduate and post-graduate, on the variable measuring education in our decomposition analyses.
} 
the ordered logistic regression models we can examine distributional changes, instead of merely changes in the average return to labor force qualifications that the more standard mean logincome decomposition details. The distribution-based decomposition allows us to understand how changing individual characteristics and changing returns to individual characteristics have affected never-married mothers' location in the income distribution, instead of looking just at mean income.

Finally we consider the changing proportion of family income resulting from income transfers from nonresident fathers and the state.

\section{RESULTS}

\section{Univariate Results}

Figure 1 displays trends in family income between 1982 and 2002 for never-married mothers; we also show the median family income for all mothers over this time period to give a better sense of how impoverished never-married mothers remain. At just over $\$ 6,000$, family incomes for never-married mothers in the bottom quartile were almost as low in 2002 as they were in 1982 . By any measure, the worst-off $25 \%$ of never-married mothers continue to be desperately poor.

Figure 1 Here

The median never-married mother has fared somewhat better. These women gained approximately $\$ 7,000$ in family income, from $\$ 8,000$ to $\$ 15,000$, between 1982 and 2002 . Although this is an increase of almost $100 \%$, their incomes in 2002 were only at the poverty line 
for a family of three (U.S. Bureau of the Census 2002b). Never-married mothers in the top 25\% of the distribution have fared best of all. Gains of about $\$ 10,000$ placed their incomes at $\$ 25,000$ in 2002. This figure is over $\$ 10,000$ higher than the median income for never-married mothers and well above the poverty line, but still far below the median family income for all mothers. Even at the $90^{\text {th }}$ and $95^{\text {th }}$ percentiles, 2002 incomes for never-married mothers were at only $\$ 39,180$ and $\$ 50,932$ respectively (results not shown), both below the median for all American mothers that year. These findings cast doubt on the existence of a burgeoning middle class of professional women who opt for unmarried motherhood (pace Hertz 2006).

Table 1 displays summary statistics for never-married mothers in 1982 and 2002, the bookends of our time series. All variables related to employment show strong gains and all changed significantly over time except for number of children. Over half of all never-married mothers were out of the labor force in 1982 . By 2002 only $21 \%$ lacked jobs, and the average SEI score had risen almost five points. In 1982, 42\% had not graduated from high school, compared to $24 \%$ in 2002 . Rates of college graduation, although still low compared to the U.S. population at large (cf. Stoops 2004), have tripled over time. The number of never-married mothers with at least some college education more than doubled over the years of the study.

Table 1 Here

Other changes since 1982 augur higher incomes for never-married mothers. Fewer had preschool-age children in $2002(60 \%)$ than in $1982(70 \%)$, even though overall fertility has not changed substantially. In recent years women were also far less likely to have their first (or only) nonmarital births while under the age of eighteen. Perhaps as a result, the average nevermarried mother in 2002 was three years older than in 1982. All of these changes should be associated with higher incomes for women who give birth out of wedlock. 
Of the four variables measuring economic assistance, public aid showed the most dramatic change over time, falling from $59 \%$ in 1982 to $14 \%$ in 2002 . This reflects the transition from AFDC to TANF in 1996. Co-residence with parents also declined. These two trends suggest that economic dependence for never-married mothers has abated. The modest increase in cohabitation among CPS participants, from $6 \%$ in 1982 to $12 \%$ in 2002 , is insufficient to have compensated for the loss of public aid or declines in co-residence with parents. ${ }^{9}$ Cohabitation rates remained sufficiently low that collectively unmarried partners have not provided a great deal of economic relief for never-married mothers in general, even if individual partners provide substantial support. Finally, child support receipt approximately doubled between 1982 and 2002. Nevertheless, at $25 \%$ receipt remained low in 2002 , even in comparison to divorced mothers (cf. Grall 2003).

\section{Regression of Mean Income}

Table 2 displays results from the regression of logged family income for never-married mothers between 1982 and 2002. Looking first at Model 1, an $R^{2}$ of .37 suggests that the independent variables are accounting for substantial variation in income. Women who did not graduate from high school report the lowest incomes, while college graduates have the highest. The biggest increase in income comes from college attendance short of graduation. Perhaps this corresponds to women with remunerative two year technical degrees. Surprisingly women with advanced degrees fare a bit worse than their counterparts with bachelor degrees.

\footnotetext{
${ }^{9}$ These figures are probably low because cohabiting relationships tend to be short and unstable (Bumpass and Lu 2000; Wolfinger 2005).
} 


\section{Table 2 Here}

Occupational characteristics have predictable effects. SEI is positively related to higher incomes; the larger coefficient on the first segment of the piecewise spline shows this is particularly true for women with SEI scores below 40. CPS participants with full-time jobs do better than those working part-time, who in turn make more money than those who are not working. Age has the standard curvilinear relationship to income, while African-Americans have significantly lower incomes than do members of other population groups. In addition, cohabiting mothers and never-married mothers living with their own parents have lower incomes, presumably because their housemates provide money or other resources.

Model 1 shows that women with more children have higher incomes. Earlier research finds an incremental wage penalty associated with children (Avellar and Smock 2003; Budig and England 2001; Waldfogel 1997); our results differ because we are looking at overall family income, not wages (see Footnote 3). Although multiple children limit labor force participation, they increase income transfers. Public aid went to less than a third of women with a single child, compared to nearly two-thirds of those with three or more children (result not shown). Model 1 also shows that the presence of children under age six has the anticipated negative relationship to income.

The most intriguing finding concerns survey year. Figure 1 shows modest increases in never-married mothers' incomes since 1982, yet the regression coefficient measuring the effect of calendar year on income, reported at the top of Table 2, is negative. Net of other independent variables, women who give birth out of wedlock are making less money now than in the early 1980s. Put another way, the modest economic gains achieved by the women in our sample are entirely attributable to changes in education, employment, SEI, and other independent variables. 
Another unexpected finding concerns the dummy variable measuring whether women first gave birth prior to age eighteen. ${ }^{10}$ Predictably the zero order relationship between birth timing and income is negative: women who first gave birth out of wedlock before age eighteen fare worse economically (result not shown). But net of the measured sociodemographic characteristics in Model 1, women in our sample who first gave birth out of wedlock as younger teenagers have higher incomes. Additional analyses, not shown, reveal that age is the independent variable responsible for the positive relationship between age at first birth and income; take age (and age squared) out of the regression model, and age at first birth has a negative relationship to income. In other words, when comparing women of the same age, those who had their first child when younger tend to have higher incomes. This might be due to the imprecision of age as a proxy for work experience: women of similar ages whose first child is younger have likely experienced more recent labor market interruptions.

Our next analytic objective is to understand how the correlates of income for nevermarried mothers have changed. This is accomplished by interacting survey year with the other independent variables. Statistically significant terms are retained in the analysis presented in Model 2 of Table 2. This model shows that the effects of most of the variables measuring labor force characteristics have remained constant over time. Education is as important in 2002 as in 1982. So is SEI. However, both part- and full-time employment have significant and positive interactions with survey year. Having a job is now associated with higher incomes for nevermarried mothers than in 1982. Given dramatically decreasing levels of public aid receipt over

\footnotetext{
${ }^{10}$ The large negative coefficient for missing data on age at first birth makes sense. Most of these women reside in households too complex to be properly captured by CPS data (e.g., with multiple generations of multiple families), and such living arrangements are often related to lower incomes.
} 
these years, presumably cemented by the imposition of time limits on welfare in 1996, it is understandable that being part of the labor force is now a more important source of income.

Coefficients representing interactions between having two or three (or more) children and survey year are both negative and statistically significant. Predicted probabilities, not shown, indicate that multiple children increased women's incomes in 1982 but decreased them in 2002. In 1982, when AFDC provided the lion's share of income for never-married mothers (see Table 4, below), each additional child raised entitlement to public assistance. By 2002, children conferred fewer monetary benefits because government aid had decreased and children precluded consistent employment.

The only other statistically significant interaction in Model 2 concerns the effects of living with parents: over time, this provided more economic benefit to never-married mothers. This result presumably reflects the increasing importance of labor force participation. Coresidential parents can provide child care, which in turn facilitates employment.

\section{Decomposition of Changes in Mean Log-Income}

We further explore the shifting economic fortunes of never-married mothers by decomposing changes in mean log-income between 1982 and 2002 (Duncan 1968; Oaxaca 1973). This allows us to determine whether higher incomes reflect changes in the attributes of never-married mothers, or changing returns to these attributes. The first column in Table 3 uses 2002 as the standard for the decomposition (that is, multiplying 2002 slopes by changes in means, and 2002 means by changes in slopes), and the second column uses 1982.

Table 3 Here 
Using either year as the standard, changes in the characteristics of never-married mothers should have resulted in income gains that were two to three times larger than what actually occurred. Although average log-incomes grew by a value of .39, as reported on the first line of Table 3, the totals under 'Difference in Characteristics' show that never-married mothers' incomes should have increased far more. The main factors driving the observed income growth are changes in employment characteristics, noted in the 'Employment' row: working hours, occupational status and experience (as measured by age and age-squared). Together these produced $86 \%(1.02 / 1.20)$ of the total effect for this section of the table when 2002 is used as the standard, and $72 \%(.52 / .73)$ of the total effect using 1982 as the standard. Gains in education also helped account for rising incomes, as did changes in fertility, co-residence with parents, and cohabitation.

The 'Differences due to Returns' panel of the decomposition confirms that economic returns to personal characteristics were lower in 2002 than in 1982 . This is largely reflected by a noteworthy decline in the intercept, which more than offsets gains due to employment. As shown in the bottom row of Table 3, the portion of growth in average log-income between 1982 and 2002 due to the interaction of changes in characteristics and returns is negative when 2002 is the standard. This again indicates the lower valuation in 2002, compared to 1982, of personal characteristics. Although more never-married mothers are working, and in better jobs, they are not being rewarded for their efforts.

\section{Decomposition of Changing Income Distributions}


The decomposition reported above allows us to determine which measured characteristics can account for the lower economic returns never-married mothers have received on average in recent years. Based on mean log-incomes, these decompositions do not provide insight into how changing individual characteristics — and diminished returns to these characteristics- have affected never-married mothers at different points of the income distribution. We therefore conduct a second series of decompositions, based on ordered logistic regressions of income rank distribution (Fortin and Lemieux 1998), for never-married mothers in 1982 and 2002.

Figure 2 plots the observed distributions for 1982 and 2002 based on the analysis of income rank. The two density lines are essentially mirror images of one another, with the most dramatic transformations occurring in the middle of both distributions. Both exhibit mild kurtosis, with clear modal groups and less defined adjacent concentrations of individuals. In 1982 the mode occurred closer to the bottom of the distribution, with a smaller concentration of women faring just slightly better. By 2002 this pattern had reversed. The mode was closer to the center of the distribution, with a smaller concentration of never-married mothers faring slightly worse. Perhaps more interesting are the tails of the two distributions. For both years very few cases fell into the far right of either distribution. Thus for both years there were almost no "Murphy Browns," women who managed to have both high incomes and nonmarital births. Nor has the proportion of such women increased over time. However, fewer cases fell into the far left of the 2002 distribution than the 1982 distribution, suggesting that the number of desperately poor never-married mothers has declined slightly. In general, more cases fall into the left tail than the right; that is to say, far more never-married mothers are disproportionately poor than are disproportionately well off (cf. M. Martin 2006).

Figure 2 Here 
Figure 3 shows "counterfactual" density plots of income distributions, based on the aforementioned ordered logistic regressions of income rank distributions. The smooth line, included for comparative purposes, depicts the predicted densities for 1982 shown in Figure 2. The line marked with circles plots estimates calculated from the 1982 model and the 2002 data. This line represents a counterfactual income distribution: if never-married mothers had 2002 levels of personal and vocational characteristics but were still receiving the same economic returns to these characteristics they had received in 1982. The line marked with triangles plots figures calculated from the 2002 model and the 1982 data, showing what the income distribution would be if never-married mothers in 1982 were receiving the economic returns to characteristics their counterparts received in 2002. These plots allow us to determine whether changes in individual attributes or the labor market--that is, returns to individual attributes--were more responsible for the changing economic fortunes of women who have children out of wedlock. $^{11}$

\section{Figure 3 Here}

The decomposition confirms that never-married mothers are doing better in 2002 due to changes in their employment-relevant attributes. The line depicting 1982 data but the 2002 model closely resembles the predicted values for 1982. This supports the results of our decomposition of means, leading us to conclude that any improvement in never-married mother's economic prospects is due to their changing personal and vocational characteristics, not higher levels of returns to any given set of characteristics. Most notably, the typical never-

\footnotetext{
${ }^{11}$ Unfortunately there is no way to perform a partial standardization (e.g., to use 1982 values on some independent variables and 2002 values on others) to determine which predictors have been particularly important to nevermarried mothers' economic progress. Although a subset of means in a standard decomposition can easily be switched, partial distributions in this type of analysis cannot be.
} 
married mother is older, more likely to be working, has higher SEI scores, and has more education than in the past. These attributes are responsible for their modest economic progress throughout the income distribution, although on the basis of Figure 3 the highest proportional shift was that of never-married mothers in the middle of the distribution into higher income brackets. This is the story told by the counterfactual distribution for the 1982 model and the 2002 data, which is shifted to the right of the observed distribution for 1982. Although nevermarried mothers in general are faring better, very few are really doing well when it comes to their location in the income distribution.

\section{Economic Dependence}

To what extent have the modest economic gains of never-married mothers been affected by dependence on income transfers? Table 1 indicates that fewer CPS participants now benefit from such transfers, but does not show the extent to which the women still receiving income transfers depend on them. Have the average economic gains of never-married mothers been driven in part by greater dependence — albeit by fewer recipients—on child support or public aid?

To address this question, we measure dependence by computing the percentage of total family income attributable to public aid or child support. ${ }^{12}$ Median levels of dependence for

\footnotetext{
${ }^{12}$ We do not, as one anonymous reviewer suggested, dispute the notion that child support is the legal right of the child and the responsibility of the nonresidential parent. This does not change the fact that never-married mothers depend upon the fathers of their children (or the government) for this income. Therefore we refer to dependent income as revenue that is not directly under the control of the mothers in our study but instead is dependent on others' actions.
} 
each income source are shown for 1982 and 2002 in Table 4. Neither can account for the income trends described in this paper. For the median recipient, child support provided $17 \%$ of total income in 1982 , but only $11 \%$ in 2002 . This is understandable given that the median annual support payment in 2002 was a paltry $\$ 630$. The transformation has been even more dramatic for public aid dependence. In 1982, it was the sole source of income for most of its recipients. In contrast, public aid provided just $38 \%$ of all income for the median recipient by 2002 . Even dependence based on the combined receipt of both child support and public aid has abated. Seven percent of mothers received both types of income transfers in 1982 , compared to $3 \%$ in 2002. Although child support and public aid together produced the vast majority of income for dual recipients in 1982 , they constituted only $41 \%$ of total income for the few never-married mothers receiving both kinds of transfer income in 2002. These results show never-married mothers were less economically dependent in 2002 than in 1982.

Table 4 Here

Economic dependence may also take the form of co-residence with parents or an unmarried partner. As shown in Table 1, co-residence with parents declined from 29\% to 19\%, while nonmarital cohabitation increased from $6 \%$ to $12 \%$ over the years of our study (see Table 1). This is a relatively small increase that has at best brought higher living standards to just a few never-married mothers.

\section{CONCLUSION}

There are four stereotypes about women who give birth out of wedlock: they are 1) young, often teenagers; 2) likely to be non-White minorities; 3) often living in multigenerational 
households with their own mothers; and 4) poor. All four of these stereotypes have become less accurate since the early 1980s. Never-married mothers are younger on average than their married counterparts, but it no longer makes sense to describe them as teenage mothers. Almost two-thirds are now twenty or over when they first give birth. Never-married mothers are also more likely to be White than in the past, less likely to be African-American, and less likely to live with their own parents.

The fourth stereotype - that never-married mothers are poor-is also less true today than in 1982. Unfortunately their economic gains have been marginal. Never-married mothers at the bottom of the income distribution have made almost no headway, while those at the median and upper quartile achieved only modest income growth. Even at the top of the distribution there are few incomes that compare with those of two-parent families. Never-married mothers continue to languish in poverty despite impressive gains in education and other personal and vocational characteristics that should have resulted in greater economic progress.

Viewed more broadly, our results do not accord with the conventional story of stratification and poverty (Morris and Western 1999). The conventional story is that many Americans are poor because of their relationship to the labor market: they lack the skills and the jobs necessary to earn higher wages. Certainly this has been the case when attempting to explain the economics of marital disruption. Higher earning power, the result of both education and better jobs, appears to be the reason for divorcées' rising incomes (McKeever and Wolfinger 2001, 2005). Although never-married mothers have achieved comparable educational and professional gains, economic returns have not followed suit. Even well-educated never-married mothers who struggle to work might find themselves thinking "thanks for nothing" as they survey their family's bottom line. 
Our findings speak to disadvantages more substantial than can be measured with CPS data. Most likely they are present long before the nonmarital childbirth occurred. In this respect, our findings regarding lower-than-expected returns to labor force characteristics are consistent with studies suggesting that teenage mothers would be poor even had they not had children (see, especially, Hotz, McElroy, and Sanders 2005). These disadvantages may well be transmitted between generations, as women who give birth out of wedlock are themselves likely to have been raised in poverty and to have endured unstable families of origin (Wu 1996). Growing up under these conditions may produce the lasting disadvantage that limits these mothers' ability to succeed in the labor market, even if they are older and better educated than previous generations of never-married mothers. Changes in the structure of the economy might also have contributed to the ongoing economic woes of women who give birth out of wedlock. As the labor market has increasingly divided itself into good jobs and bad jobs, never-married mothers seem to have been caught on the wrong side of the split. If this is the case, it will take more than job placement programs to lift them out of poverty.

Although income is of vital importance to never-married mothers and their children, it is not the only measure of how this chronically challenged population is faring. For women coming off welfare, employment may have noteworthy non-monetary benefits. Work can benefit women's self-esteem while instilling desirable values in children (London et al. 2004), although women moving from welfare to work may spend less time with their children (Edin and Lein 1997). These are noteworthy concerns for a population facing such profound disadvantage. 


\section{REFERENCES}

Avellar, Sarah, Smock Pamela J., 2003. Has the Price of Motherhood Declined Over Time? A Cross-Cohort Comparison of the Motherhood Wage Penalty. Journal of Marriage and Family 65, 597-607.

Blank, Rebecca M, 1998. It Takes a Nation, updated edition. Princeton University Press, Princeton. ,2002. Evaluating Welfare Reform in the United States. Working paper 8983, National Bureau of Economic Research, Cambridge, MA.

Budig, Michelle J., England, Paula, 2001. The Wage Penalty for Motherhood. American Sociological Review 66:204-225.

Bumpass, Larry L., Lu, Hsien-Hen, 2000. Trends in Cohabitation and Implications for Children's Family Contexts in the United States. Population Studies 54:29-41.

Bumpass, Larry L., Raley, R. Kelly 1995. Redefining Single-Parent Families: Cohabitation and Changing Family Reality. Demography 32:97-109.

Casper, Lynne M., Cohen, Philip N. 2000. How Does POSSLQ Measure Up? Historical Estimates of Cohabitation. Demography 37:237-245.

Coleman, James, 1988. Social Capital in the Creation of Human Capital. American Journal of Sociology 94:S95-S120.

Collins, Gail, 2009. When Everything Changed: The Amazing Journey of American Women from 1960 to the Present. Little, Brown, and Company, New York. 
Congressional Committee on Ways and Means, 2004. Green Book. Background Material and Data on the Programs within the Jurisdiction of the Committee on Ways and Means (http://www.gpoaccess.gov/wmprints/green/index.html).

Correll, Shelley J., Benard, Stephen, Paik, In, 2007. Getting a Job: Is There a Motherhood Penalty? American Journal of Sociology 112:1297-1338.

Dalaker, Joseph, 2001. Poverty in the United States: 2000, Current Population Reports, P60-214, U.S. Bureau of the Census, Washington, D.C.

Davis, Shannon N., Greenstein, Theodore N., Marks, Gerteisen, Jennifer P., 2007. Effects of Union Type on Division of Household Labor. Journal of Family Issues 28:1246-1272.

DeNavas-Walt, Carmen, Proctor, Bernadette D., Mills, Robert J., 2004. U.S. Census Bureau, Current Population Reports, P60-226, Income, Poverty, and Health Insurance Coverage in the United States: 2003, U.S. Government Printing Office, Washington, DC.

Duncan, Otis Dudley, 1968. Inheritance of Poverty or Inheritance of Race? In: Moynihan, Daniel P. (Ed.), On Understanding Poverty. Basic Books, New York, pp. 85-110.

Edin, Kathryn, Lein, Laura, 1997. Making Ends Meet. Russell Sage Foundation, New York.

Ellwood, David, Jencks, Christopher, 2004. The Spread of Single-Parent Families in the United States since 1960. In: Moynihan, Daniel P., Rainwater, Lee, Smeeding, Tim (Eds.), The Future of the Family. Russell Sage, New York, pp 25-65.

England, Paula, 1992. Comparable Worth: Theories and Evidence. Aldine de Gruyter, Hawthorne, NY. 
Fischer, Claude S., Hout, Michael, 2006. Century of Difference: How America Changed in the Last One Hundred Years. Russell Sage Press, New York.

Fields, Jason, 2003. America's Families and Living Arrangements: 2003. Current Population Reports, P20-553. U.S. Bureau of the Census, Washington D.C.

Fortin, Nicole M., Lemieux, Thomas, 1998. Rank Regressions, Wage Distributions, and the Gender Gap. The Journal of Human Resources 33:610-643.

Foster, E. Michael, Jones, Damon, Hoffman, Saul D., 1998. The Economic Impact of Nonmarital Childbearing: How are Older, Single Mothers Faring? Journal of Marriage and the Family 60:163-174.

Geronimus, Arline T., Korenman, Sanders, 1992. The Socioeconomic Consequences of Teen Childbearing Reconsidered. Quarterly Journal of Economics 107:1187-1214.

Grall, Timothy, 2003. Custodial Mothers and Fathers and Their Child Support: 2001. Current Population Reports, P60-225. U.S. Bureau of the Census, Washington, D.C. Grogger, Jeff, Bronars, Stephen, 1993. The Socioeconomic Consequences of Teenage Childbearing: Findings from a Natural Experiment. Family Planning Perspectives $25: 156-161,174$.

Grogger, Jeffrey, Karoly, Lynn A., 2005. Welfare Reform: Effects of a Decade of Change. Harvard University Press, Cambridge, MA.

Hastie, Trevor J., Tibshirani, Rob J., 1990. Generalized Additive Models. Chapman \& Hall, London.

Hauser, Robert M., Warren, John Robert. 1997. Socioeconomic Indexes of Occupational Status: A Review, Update, and Critique. In: Raftery, Adrian (Ed.) Sociological Methodology, Cambridge: Blackwell Publishers, pp. 177-298. 
Heimdal, Kristen R., Houseknecht, Sharon K, 2003. Cohabiting and Married Couples' Income Organization: Approaches in Sweden and the United States. Journal of Marriage and Family 65:525-538.

The Heritage Foundation, 2004. Marriage Promotion.

(http://www.heritage.org/Research/Features/Issues2004/MarriageWelfarePoverty.cfm).

Hertz, Rosanna, 2006. Single by Chance, Mothers by Choice. Oxford University Press, New York.

Hoffman, Saul D, 1998. Teenage Childbearing Is Not So Bad After All...Or Is It? A Review of the New Literature. Family Planning Perspectives 30:236-239, 243.

Hoffman, Saul D., Foster, E. Michael, Furstenberg, Frank F. Jr, 1993. Reevaluating the Costs of Teenage Childbearing. Demography 30:1-13.

Hotz, V. Joseph, McElroy, Susan Williams, Sanders, Seth G., 2005. Teenage Childbearing and Its Life Cycle Consequences: Exploiting a Very Natural Experiment. Journal of Human Resources 40:683-715.

Kymlicka, B. B., Matthews, Jean V., eds, 1988. The Reagan Revolution? Dorsey Press, Chicago. Jones, F. L., Kelley, Jonathan, 1984. Decomposing Differences Between Groups: A Cautionary Note on Measuring Discrimination. Sociological Methods and Research 12: 323-343.

Lekachman, Robert, 1982. Greed is Not Enough. Pantheon Books, New York.

Lichter, Daniel T., Eggebeen, David J., 1994. The Effect of Parental Employment on Child Poverty. Journal of Marriage and the Family 56:633-645.

Lichter, Daniel, Graefe, Deborah Roempke, 2001. Finding a Mate? The Marital and Cohabitation Histories of Unwed Mothers. In: Wu, Larry L., Wolfe, B (Eds.), Out of Wedlock. Russell Sage, New York, pp. 317-343. 
Lichter, Daniel T., Graefe, Deborah Roempke, Brown, J. Brian, 2003. Is Marriage a Panacea? Union Formation Among Economically Disadvantaged Unwed Mothers. Social Problems 50:60-86.

London, Andrew S., Scott, Ellen K., Edin, Kathryn, Hunter, Vicki, 2004. Welfare Reform, Work-Family Tradeoffs, and Child Well-Being. Family Relations 53:148-158.

Manning, Wendy D., Smock, Pamela J., 2005. Measuring and Modeling Cohabitation: New Perspectives from Qualitative Data. Journal of Marriage and Family 67:989-1002.

Martin, Joyce A., Hamilton, Brady E., Sutton, Paul D., Ventura, Stephanie J., Menacker, Fay, Kirmeyer, Sharon, Mathews, T. J., 2009. Births: Final Data for 2006. National Vital Statistics Reports, Vol. 57, No. 7. Hyattsville, MD: National Center for Health Statistics.

Martin, Molly A, 2006. Family Structure and Income Inequality in Families with Children, 1976 to 2000. Demography 43:421-445.

McKeever, Matthew, Wolfinger, Nicholas H. 2001. Reexamining the Economic Consequences of Marital Disruption for Women. Social Science Quarterly 82:202-217. , 2005. Shifting Fortunes in a Changing Economy: Trends in the Economic Well-Being of Divorced Women. In: Kowaleski-Jones, Lori, Wolfinger, Nicholas H., Fragile Families and the Marriage Agenda. Springer, New York, pp. 127-157.

McLanahan, Sara, 2004. Diverging Destinies: How Children Fare Under the Second Demographic Transition. Demography 41:607-627. , 2005. Fragile Families and the Marriage Agenda. In: Kowaleski-Jones, Lori, Wolfinger, Nicholas H., Fragile Families and the Marriage Agenda. Springer, New York, pp. 1-21. 
Morris, Martina, Western, Bruce, 1999. Inequality in Earnings at the Close of the Twentieth Century. Annual Review of Sociology 25:623-657.

Nichols-Casebolt, Ann M, 1988. Black Families Headed by Single Mothers: Growing Numbers and Increasing Poverty. Social Work, July-August, 306-313.

Oaxaca, Ronald, 1973. Male-Female Wage Differentials in Urban Labor Markets. International Economic Review 14:693-709.

Paul, Christopher, Mason, William M., McCaffrey, Daniel, Fox, Sarah A., 2008. A Cautionary Case Study of Approaches to the Treatment of Missing Data. Statistical Methods and Applications 17:351-372.

Peterson, Janice, Song, Xue, Jones-DeWeever, Avis, 2002. Life after Welfare Reform: LowIncome Single Parent Families, Pre- and Post-TANF. Research-in-Brief \#D446, Institute for Women's Policy Research, Washington, DC.

Proctor, Bernadette D., Dalaker, Joseph, 2003. U.S. Census Bureau, Current Population Reports, P60-222, Poverty in the United States: 2002, U.S. Government Printing Office, Washington, DC.

Smock, Pamela J., Manning, Wendy, Gupta, Sanjiv, 1999. The Effect of Marriage and Divorce on Women's Economic Well-Being. American Sociological Review 64:794-812.

Stack, Carol B, 1974. All Our Kin: Strategies for Survival in a Black Community. Harper and Row, New York.

Stoops, Nicole, 2004. Educational Attainment in the United States: 2003. Current Population Reports, P20-550. U.S. Census Bureau, Washington, D.C.

Thurow, Lester C, 1969. The Optimum Lifetime Distribution of Consumption Expenditures. The American Economic Review 59:324-330. 
Treiman, Donald J., Hartmann, Heidi, eds, 1981. Women, Work, and Wages: Equal Pay for Jobs of Equal Value. National Academy Press, Washington, D.C.

United States Bureau of the Census, 1999. Money Income in the United States: 1999. Current

Population Reports, P60-209. U.S. Government Printing Office, Washington, D.C. , 2002a. Current Population Survey: Annual Demographic File, 2002, Bureau of Labor

Statistics, Washington, D.C. (http://www.bls.census.gov/cps/cpsmain.htm). , 2002b. Poverty 2002. (http://www.census.gov/hhes/poverty/threshld/thresh02.html). ,2003. Statistical Abstract of the United States: 2003 (123rd edition). U.S.

Government Printing Office, Washington, D.C. , 2010. Historical Income Tables - Households, Table H-4.

(http://www.census.gov/hhes/www/income/histinc/h04.html).

United States Department of Health \& Human Services, 2006. Administration for Children and

Families, Healthy Marriage Initiative. (http://www.acf.hhs.gov/healthymarriage).

Upchurch, Dawn M., Lillard, Lee A., Panis, Constantijn W. A., 2001. The Impact of Nonmarital Childbearing on Subsequent Marital Formation and Dissolution. In: Wu, Larry L., Wolfe, B (Eds.), Out of Wedlock: Causes and Consequences of Nonmarital Fertility. Russell Sage Foundation, New York, pp. 344-380.

Ventura, Stephanie J., Martin, Joyce A., Curtin, Sally C., Mathews, T. J., Park, Melissa M., 2000. Births: Final Data for 1998. National Vital Statistics Reports 48(3).

Waldfogel, Jane, 1997. The Effect of Children on Women's Wages. American Sociological Review 62:209-217

Waite, Linda, Gallagher, Maggie, 2000. The Case for Marriage. Doubleday, New York. 
Wilcox, W. Bradford, Wolfinger, Nicholas H. 2007. Then Comes Marriage? Religion, Race, and Marriage in Urban America. Social Science Research 36:569-589

Wolfinger, Nicholas H, 2005. Understanding the Divorce Cycle: The Children of Divorce in Their Own Marriages. Cambridge University Press, New York.

Wu, Lawrence L, 1996. Effects of Family Instability, Income, and Income Instability on the Risk of a Premarital Birth. American Sociological Review 61:386-406.

Wu, Lawrence L., Bumpass, Larry L., Musick, Kelly, 2001. Historical and Life Course Trajectories of Nonmarital Childbearing. In: Wu, Larry L., Wolfe, B (Eds.), Out of Wedlock: Causes and Consequences of Nonmarital Fertility. Russell Sage Foundation, New York, pp. 3-48

Wu, Lawrence L., Stojnic, Miodrag, 2007. Poverty among the Poorest-Poor in the United States: Trends for Never-Married Women and Their Children. Paper presented at the Inaugural Conference, Center for Research on Inequalities and the Life Course, Yale University, May 2007. 
Table 1. Descriptive Statistics by Year.

\begin{tabular}{|c|c|c|}
\hline Education & $\underline{1982}$ & $\underline{2002}$ \\
\hline Less than H.S. & $42 \%$ & $24 \%$ \\
\hline High school graduate & 42 & 40 \\
\hline Some college & 13 & 29 \\
\hline College graduate & 2 & 5 \\
\hline Advanced degree & .41 & 2 \\
\hline \multicolumn{3}{|l|}{ Employment } \\
\hline Not working & $51 \%$ & $21 \%$ \\
\hline $1-34$ hours & 12 & 18 \\
\hline $35+$ hours & 37 & 61 \\
\hline SEI & 24.84 & 30.44 \\
\hline Income & 10,917 & 19,492 \\
\hline Age & 27 & 30 \\
\hline \multicolumn{3}{|l|}{ Race } \\
\hline White & $24 \%$ & $34 \%$ \\
\hline Black & 67 & 47 \\
\hline Other & 9 & 19 \\
\hline \multicolumn{3}{|l|}{ Children } \\
\hline 1 & $55 \%$ & $57 \%$ \\
\hline 2 & 28 & 27 \\
\hline $3+$ & 17 & 16 \\
\hline \multicolumn{3}{|l|}{ Children under 6} \\
\hline Yes & $70 \%$ & $60 \%$ \\
\hline No & 30 & 40 \\
\hline \multicolumn{3}{|l|}{ Age of first birth } \\
\hline$<18$ & $24 \%$ & $10 \%$ \\
\hline $18-19$ & 28 & 27 \\
\hline $20+$ & 48 & 64 \\
\hline \multicolumn{3}{|l|}{ Receiving public aid } \\
\hline Yes & $59 \%$ & $14 \%$ \\
\hline No & 41 & 86 \\
\hline \multicolumn{3}{|l|}{ Receiving child support } \\
\hline Yes & $13 \%$ & $25 \%$ \\
\hline No & 87 & 75 \\
\hline \multicolumn{3}{|l|}{ Living with parents } \\
\hline Yes & $29 \%$ & $19 \%$ \\
\hline No & 71 & 81 \\
\hline \multicolumn{3}{|l|}{ Cohabiting } \\
\hline Yes & $6 \%$ & $12 \%$ \\
\hline No & 94 & 88 \\
\hline
\end{tabular}

Notes: Ns are 997 for 1982 and 3,133 for 2002. Numbers are weighted.

Percentages may not sum to 100 due to rounding error.

All means and percentages differ significantly $(p<.001)$ between 1982 except for number of children.

Source: 1982 and 2002 Current Population Survey March Demographic File. 
Table 2. OLS Regressions of Family Log-Income, 1982-2002.

\begin{tabular}{|c|c|c|c|c|}
\hline \multirow[b]{2}{*}{ Year } & \multicolumn{2}{|c|}{ Model 1} & \multicolumn{2}{|c|}{ Model 2} \\
\hline & $-.024^{* * *}$ & $(.002)$ & .008 & $(.026)$ \\
\hline \multicolumn{5}{|l|}{ Race } \\
\hline White & -- & & -- & \\
\hline Black & $-.153^{* \star *}$ & $(.022)$ & $-.154^{\star \star \star}$ & $(.024)$ \\
\hline Other & $-.098^{* *}$ & $(.030)$ & $-.088^{\star \star}$ & $(.029)$ \\
\hline \multicolumn{5}{|l|}{ Education } \\
\hline Less than H.S. & -- & & -- & \\
\hline H.S. graduate & $.095^{* * *}$ & $(.026)$ & -5.748 & $(8.375)$ \\
\hline Some college & $.255^{\star \star \star}$ & $(.030)$ & $-20.437^{\star}$ & $(9.501)$ \\
\hline College graduate & $.295^{\star \star \star}$ & $(.046)$ & $-63.385^{\star \star \star}$ & (17.024) \\
\hline Advanced degree & $.225^{\star *}$ & (.078) & $-74.791^{\star *}$ & $(25.332)$ \\
\hline Year*H.S. graduate & -- & & .003 & $(.004)$ \\
\hline Year*some college & -- & & $.010^{*}$ & $(.005)$ \\
\hline Year*college graduate & -- & & $.032^{* * *}$ & $(.009)$ \\
\hline Year*advanced degree & -- & & $.038^{\star *}$ & $(.013)$ \\
\hline SEI to 40 & $.025^{\star * *}$ & $(.001)$ & $.023^{* * *}$ & $(.001)$ \\
\hline SEI $41+$ & $.007^{* *}$ & $(.002)$ & $.007^{* * *}$ & $(.002)$ \\
\hline \multicolumn{5}{|l|}{ Children } \\
\hline One & -- & & -- & \\
\hline Two & $.112^{\star \star \star}$ & $(.024)$ & $33.944^{* * *}$ & $(7.281)$ \\
\hline Three+ & $.295^{\star * *}$ & $(.031)$ & $40.517^{\star * *}$ & (8.939) \\
\hline Year*two children & -- & & $-.017^{\star \star \star}$ & $(.004)$ \\
\hline Year*three+ children & -- & & $-.020^{\star \star \star}$ & $(.004)$ \\
\hline Child under six & -.031 & $(.025)$ & -.036 & $(.025)$ \\
\hline Age & $.102^{* * *}$ & $(.012)$ & $9.010^{* *}$ & $(3.337)$ \\
\hline $\mathrm{Age}^{2} / 100$ & $-.108^{* * *}$ & $(.018)$ & $-13.631^{* *}$ & $(5.153)$ \\
\hline Year*age & -- & & $-.004^{\star *}$ & $(.002)$ \\
\hline $\mathrm{Year}^{*} \mathrm{Age}^{2} / 100$ & -- & & $.006^{* *}$ & $(.002)$ \\
\hline Living with parents & $-.9556^{\star \star \star}$ & $(.029)$ & $-24.324^{*}$ & $(9.530)$ \\
\hline Year*living with parents & -- & & $.012^{*}$ & $(.005)$ \\
\hline \multicolumn{5}{|l|}{ Employment } \\
\hline Not working & -- & & -- & \\
\hline $1-34$ hours & $.730^{\star * \star}$ & $(.037)$ & $-117.750^{\star \star \star}$ & (10.186) \\
\hline $35+$ hours & $1.270^{\star \star \star}$ & $(.036)$ & $110.473^{\star \star \star}$ & $(9.186)$ \\
\hline Year*working 1-34 hours & -- & & $.06^{\star \star \star}$ & $(.005)$ \\
\hline Year*working $35+$ hours & -- & & $.06^{\star \star \star}$ & $(.005)$ \\
\hline Has live-in partner & $-.428^{* * *}$ & $(.025)$ & $-.418^{\star * \star}$ & $(.034)$ \\
\hline \multicolumn{5}{|l|}{ Age at first birth } \\
\hline$<18$ & $.071^{*}$ & $(.033)$ & $.068^{*}$ & $(.033)$ \\
\hline $18-19$ & .043 & $(.026)$ & .042 & $(.026)$ \\
\hline $20+$ & -- & & -- & \\
\hline Data missing & $-.450^{\star \star *}$ & $(.067)$ & $-.419^{\star \star \star}$ & $(.067)$ \\
\hline Constant & $54.066^{* * *}$ & $(3.506)$ & $-9.293^{\star \star *}$ & (51.402) \\
\hline R-square & .370 & & .380 & \\
\hline
\end{tabular}

${ }^{*} \mathrm{p}<.05 ;{ }^{* *} \mathrm{p}<.01 ;{ }^{* * *} \mathrm{p}<.001$

Notes: Analyses are weighted. $\mathbf{N}$ is 34,321 . Numbers in parentheses are standard errors.

Source: 1982-2002 Current Population Survey March Demographic File. 
Table 3. Decomposition of Mean Differences in Family Log-Income, 1982-2002.

\begin{tabular}{|c|c|c|}
\hline & 2002 as standard & 1982 as standard \\
\hline Observed Mean Difference & .3921 & .3921 \\
\hline \multicolumn{3}{|l|}{ Difference in Characteristics } \\
\hline Education & .1002 & .0418 \\
\hline Employment & 1.0247 & .5214 \\
\hline Family & .0729 & .1271 \\
\hline Age at First Birth & .0025 & .0141 \\
\hline Race & -.0033 & .0301 \\
\hline Total & 1.1971 & .7345 \\
\hline \multicolumn{3}{|l|}{ Difference in Returns } \\
\hline Intercepts & -3.0684 & -3.0684 \\
\hline Education & .0795 & .0211 \\
\hline Employment & 2.5906 & 2.0873 \\
\hline Family & -.0247 & .0294 \\
\hline Age at First Birth & -.0065 & .0051 \\
\hline Race & .073 & .1064 \\
\hline Total & -0.3565 & -0.8191 \\
\hline \multicolumn{3}{|l|}{ Interaction } \\
\hline Education & -0.0584 & .0584 \\
\hline Employment & -0.5033 & .5033 \\
\hline Family & 0.0541 & -.0541 \\
\hline Age at First Birth & 0.0116 & -.0116 \\
\hline Race & 0.0333 & -.0333 \\
\hline Total & -0.4626 & .4626 \\
\hline
\end{tabular}

Note: Ns are 997 for 1982 and 3,133 for 2002.

Source: 1982-2002 Current Population Survey March Demographic File. 
Table 4. Median Contributions of Nonemployment Earnings to Total Family Income, 1982 and 2002.

\begin{tabular}{lllll}
\hline & \multicolumn{2}{c}{1982} & & 2002 \\
\cline { 2 - 3 } \cline { 4 - 5 } $\begin{array}{l}\text { Median percentage of } \\
\text { contribution to family income }\end{array}$ & & & & \\
$\quad$ Child support & $17 \%$ & $(\$ 1,490)$ & $11 \%$ & $(\$ 599)$ \\
Public aid & $100 \%$ & $(\$ 4,469)$ & $38 \%$ & $(\$ 2,167)$ \\
Both & $90 \%$ & & $41 \%$ & \\
\hline
\end{tabular}

Notes: Figures restricted to respondents receiving each type of aid. Results are weighted.

Numbers in parentheses are median amounts in 2002 dollars.

Ns are 997 for 1982 and 3,133 for 2002.

Source: 1982 and 2002 Current Population Survey March Demographic File. 


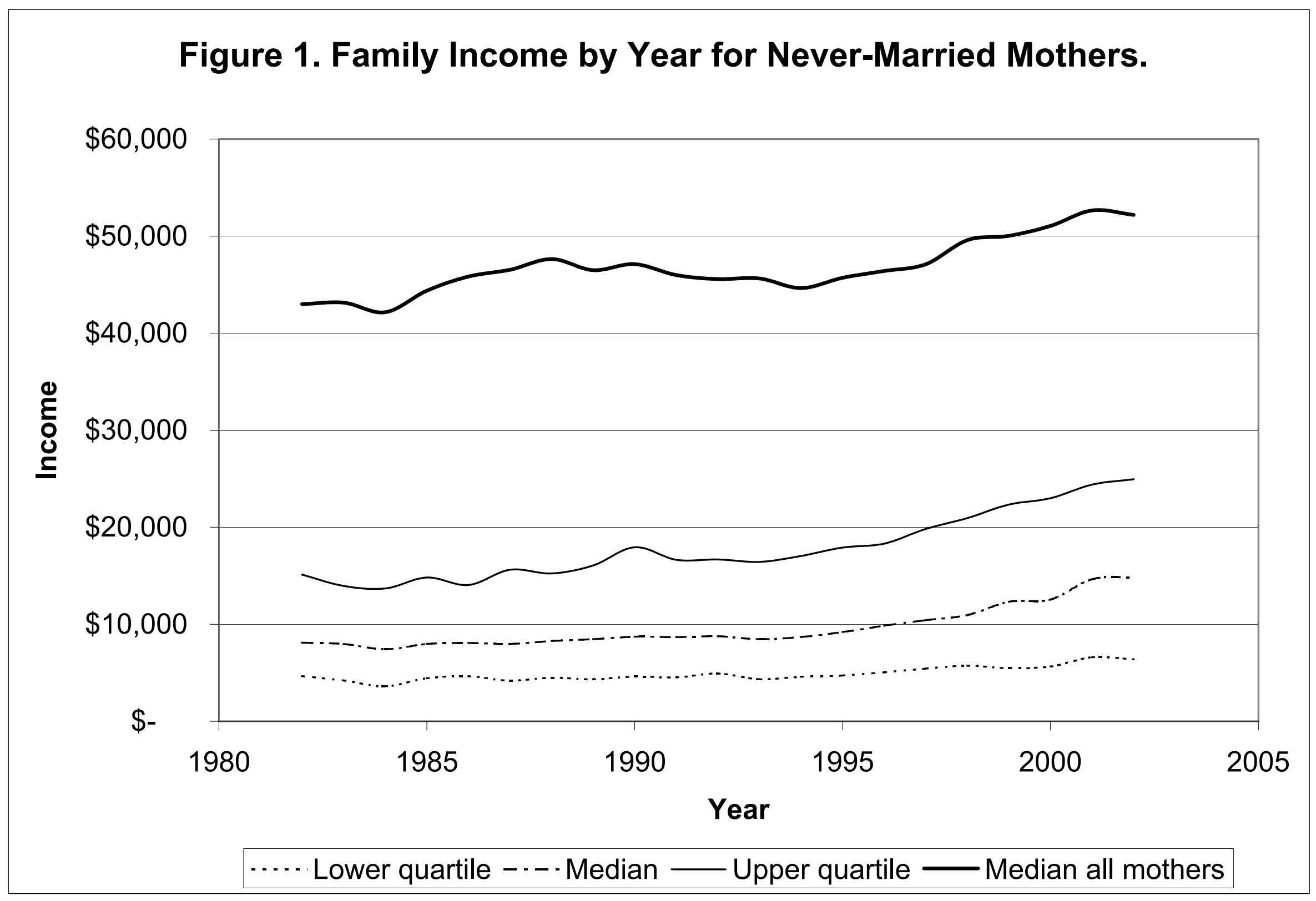




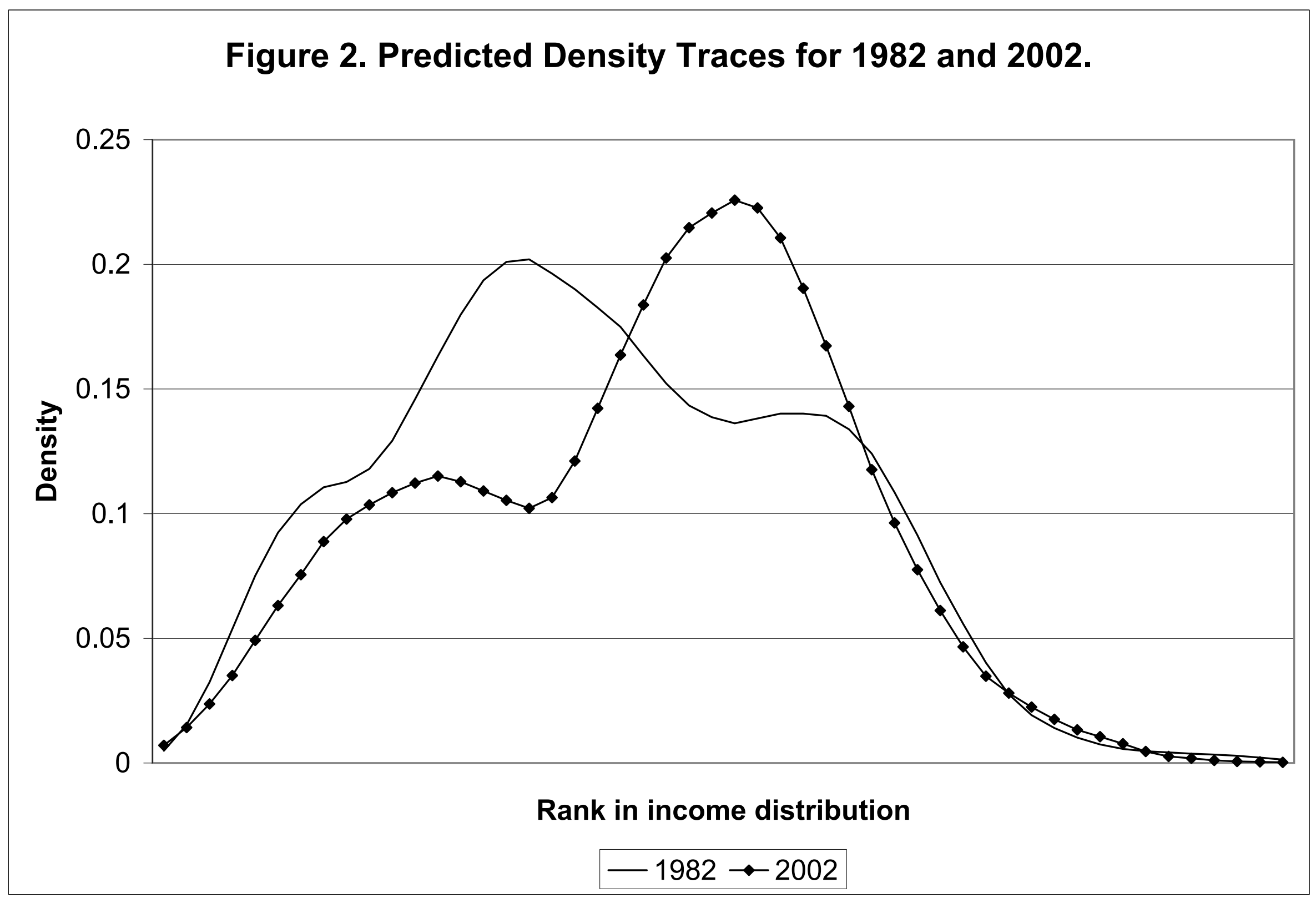




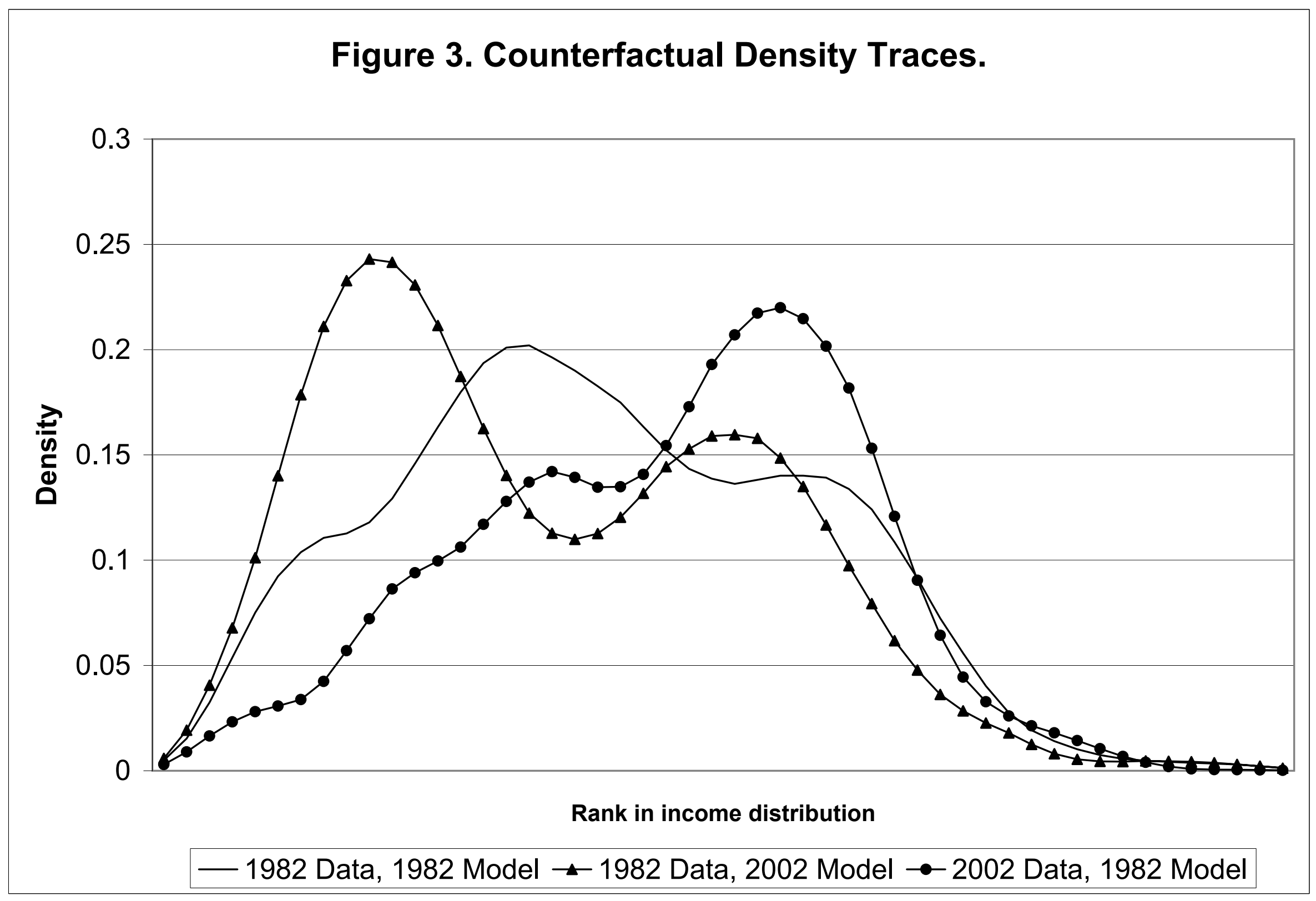

